\title{
Agricultural Urbanism: \\ Lessons from the Cultural Landscape of Messinia
}

\author{
By Steven Clarke*
}

\begin{abstract}
Agricultural urbanism is an emerging movement based around the idea of integrating sustainable food-systems and education with the design of the urban environment. A food-system includes the infrastructure and processes of feeding a population, from growing to processing, distributing to consuming, and finally, from recycling back to growing. However, a study of the cultural landscape of Messinia, Greece, provides lessons on how food-systems can be successfully utilized in the shaping and making of places. A case study method is employed in the analysis of three projects in Messinia - Trion Navarchon Square (Pylos), Ammothines Restaurant (Petrochori), and Navarino Dunes Resort (Romanos) revealing design lessons that are at the foundation of agricultural urbanism. The lessons are applied to the design of the Greenpoint Food District, Brooklyn, New York, a proposed pedestrian oriented, compact, regenerative community that has a clear identity with food cultivation. Using a four-storey, mixed-use building typology that includes civic, retail, office, and residential spaces, the building form and landscapes are carefully interwoven to create the Food District. A rooftop urban farm, supported by regenerative infrastructure and agricultural practices, contribute to a sustainable community by providing opportunities in the neighborhood for social engagement, urban regeneration, and the fostering of a local economy. As the world's population increases and the amount of farmland shrinks, there must be a shift in how we shape our urban environments. The lessons learned from the cultural landscape of Messina, provides an opportunity to better understand how to successfully integrate food with our urban environments. Food provides the opportunity to restore, invigorate, and transform how we make our communities and cities better places to live, learn, work and play. Addressing these challenges through agricultural urbanism provides the mechanism to shape the city into a distinct place dedicated to food.
\end{abstract}

\section{Introduction}

Agricultural urbanism is an emerging movement based around the idea of integrating sustainable food-systems and education with the design of the urban

*Associate Professor, University of Nevada, USA.

https://doi.org/10.30958/ajt.2-1-2

doi=10.30958/ajt.2-1-2 
environment. A food-system includes the infrastructure and processes of feeding a population, from growing to processing, distributing to consuming, and finally, from recycling back to growing. This movement emphasizes that the integration of food-systems with daily city life will contribute to the development of sustainable communities (de la Salle 2010). However, a study of the cultural landscape of Messinia, Greece, provides lessons on how foodsystems can be successfully utilized in the shaping and making of places.

A cultural landscape contains both cultural and natural resources that the related inhabitants define as heritage resources (The Cultural Landscapes Foundation 2014). Messinia is a regional unit located in the southwest region of the Peloponnese, Greece. Its capital and main port is Kalamata. A fertile landscape has cultivated an agricultural economy during the past two centuries, with the production and processing of olives, figs, and grapes, to name a few of its known crops (Kouvelakis 2006). The cultural landscape of Messinia is rich, including many cultural traditions, ranging from regional dances to agricultural practices; and layers of history, from Mycenaean culture to Byzantine fortresses (figure 1).

Figure 1. A Remnant of a Byzantine Fortress in Messinia is Part of the Region's Cultural Landscape (Photo by Author)

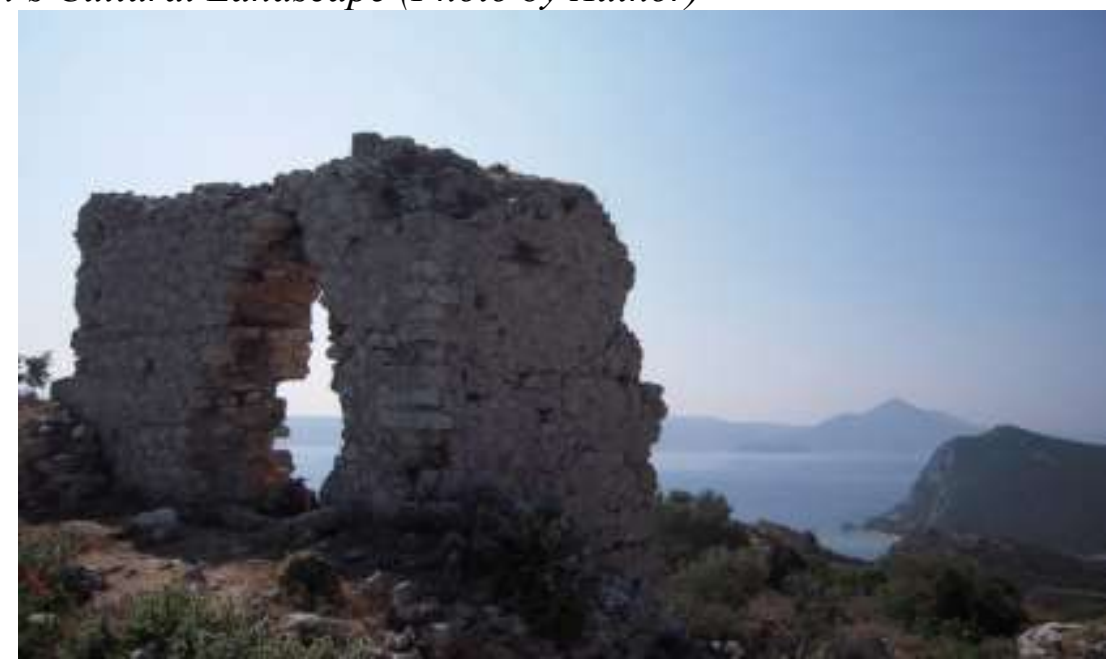

The observation of the cultural landscape of Messinia through a case study approach reveals the fundamental design concepts that are at the core of agricultural urbanism. Three (3) case studies have been selected based on their significance and impact informing the integration of food-systems with the built environment. The first, Trion Navarchon Square in Pylos, is an important outdoor amenity located at the heart of the community. The square is the oldest and most established of the case studies examined, having a built-over-time quality. Next, Ammothines Restaurant is noteworthy due to its simple inclusion of most sustainable food-systems and modest scale. The final project, Navarino Dunes, the first resort area at Costa Navarino, Romanos, is a significant large-scale case study illustrating a fusion of both traditional and modern architectural language with the complete presence of food-systems and 
education. The later two projects also illustrate how the agrarian-based economy of Messinia has responded to an emerging international tourist economy that has been developing over the last decade. Assembling the case studies involved conducting a literature review and site observation for each, and in the case of the Navarino Dunes Resort, informal interviews with its operators and designers. Through this process and analysis, design lessons emerge related to the integration of food-systems with the built environment. These lessons are then applied to the design of the proposed Greenpoint Food District in Brooklyn, New York.

\section{Case Study 1: Trion Navarchon Square, Pylos}

Figure 2. Trion Navarchon Square, Pylos, (Airphoto: Google Maps)

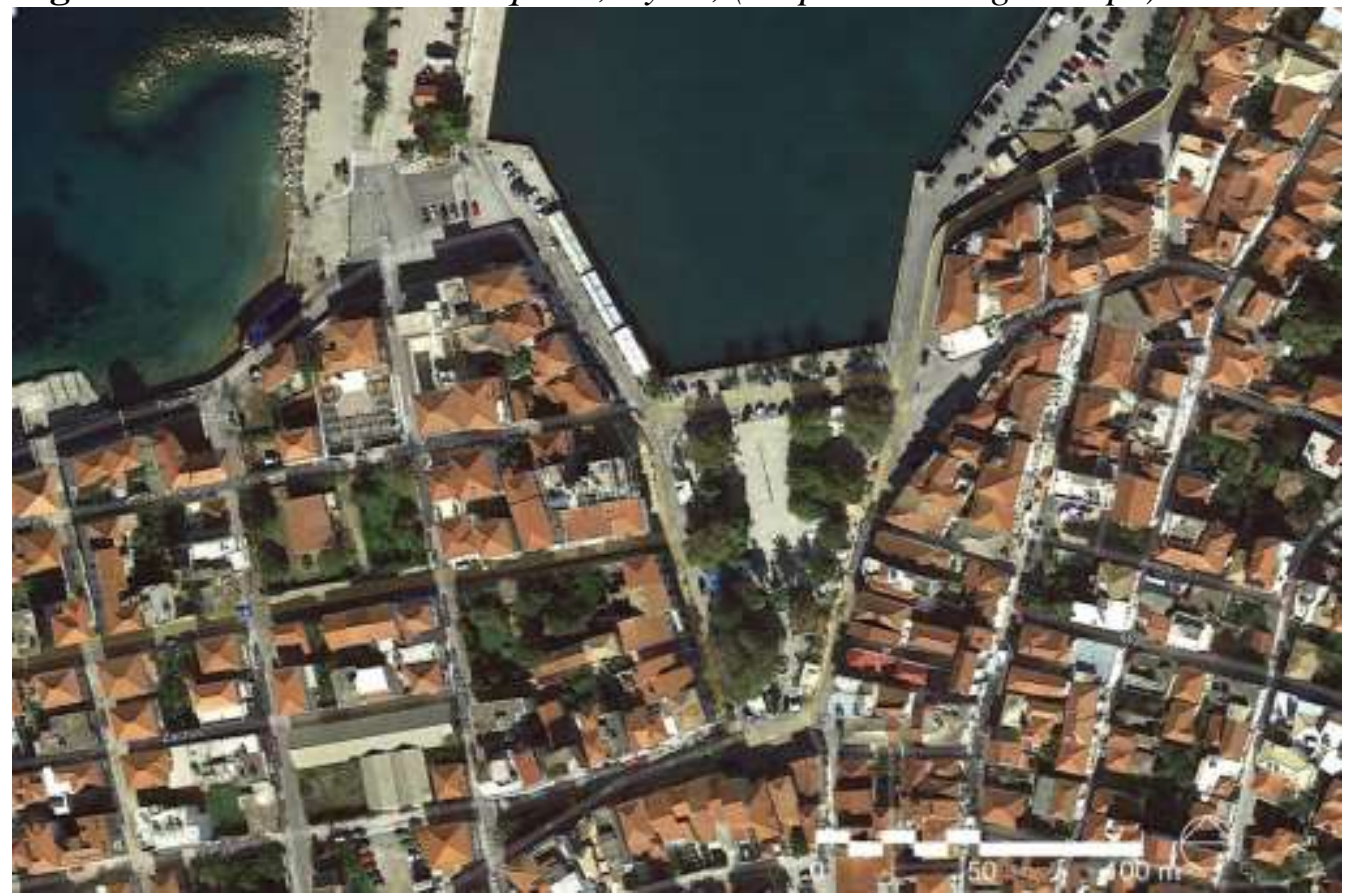

Pylos is a town located on the south coast of the Bay of Navarino. The town's framework was based on a plan established by French engineers stationed in Pylos during the Morea expedition of 1828-1833. At the heart of the community is Trion Navarchon Square, the main plaza or platia (figure 2). The form of the square was established when roads and sewers were built during the late $19^{\text {th }}$ and early $20^{\text {th }}$ centuries, (Papathanassopoulos 2000). A monument commemorating the Battle of Navarino, occupies a prominent location. This significant battle was fought on October 20,1927, during the Greek War of Independence, where an allied naval fleet of British, French, and Russia vessels defeated the Ottoman fleet. A case study of Trion Navarchon Square informs lessons related to agricultural urbanism that include retail and celebration. 


\section{Retail}

The experience of buying and selling of food in the platia has been enhanced through attention to human comfort and scale. For example, the typical architecture of the town consists of stone or white stucco, two- to threestorey construction. However, the buildings that form the edges of the platia have the unique feature of an arcade (figure 3). As a result, the retail experience along the edge of the platia is primarily under a continuous sheltered walkway. Restaurant patios spill from the arcades, across the perimeter road and into the square, where the canopy of 100 year-old plane trees and other structures provide shade. These elements offer protection from the elements to both users and merchant displays, making for a pleasant retail experience, even in the heat of the afternoon.

Figure 3. Typical Building with Arcade Defining the Edge of the Platia. Trion Navarchon Square (Photo by Author)

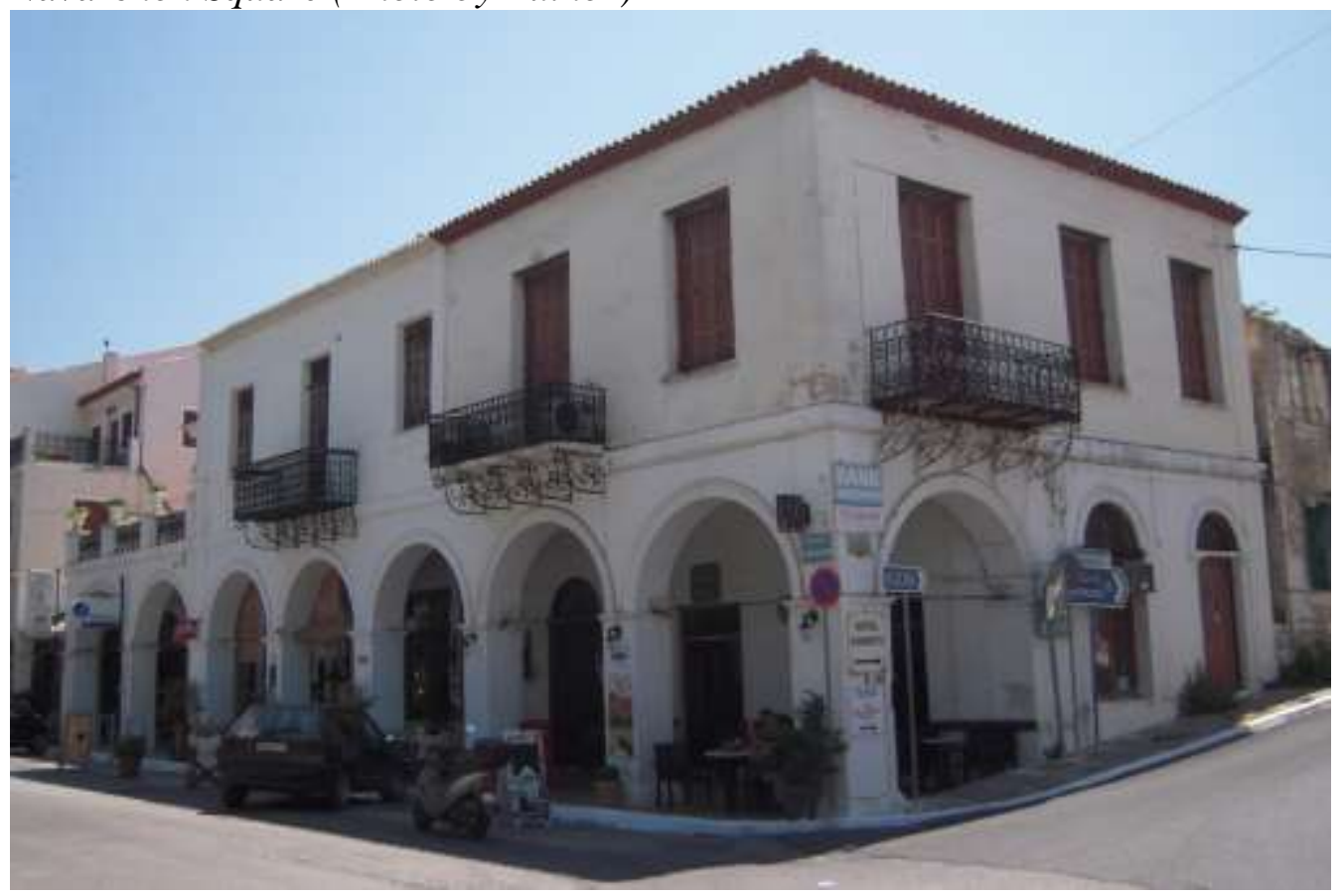

For the residents of Pylos, the retail experience is strengthened as the town streets extend into the old neighborhoods from the platia. This pattern establishes a connection for the community to a variety of food sources within a ten-minute walk. Much of the town's commercial activity can be found along the edge of the square, including pharmacies, banks, bakeries, restaurants, cafes, bars and a grocery store. Aside from the restaurant patios that spill into the square, there are three convenience kiosks, known as periptera. At the periptera, one can purchase convenience items such as drinks and snacks, among others. Thus, the relative neighborhood scale of Pylos allows for residents to live within walking distance of the platia and amenities essential for daily life. Eight to ten minutes is the length of time that the majority of people will consider walking before choosing to drive. 


\section{Celebration \& Eating}

The concentration of food amenities along the main square of Pylos brings people together to deliver, process, purchase, and consume food in one place. This concept is emphasized as the square comes alive in the evenings, with children playing in the plaza, while their families dine at the restaurants and cafés lining the edge (figure 4). The active restaurant and café patios are important examples of making food visible. This visibility and integration of food with everyday life contributes to the social meaning of the platia by supporting community vibrancy. Another benefit of making food visible is the sound of people dining and the aroma of food cooking, adding delight to the experience of urban living.

Figure 4. A Typical Summer View of the Vibrant Platia in the Early Evening. Trion Navarchon Square (Photo by Author)

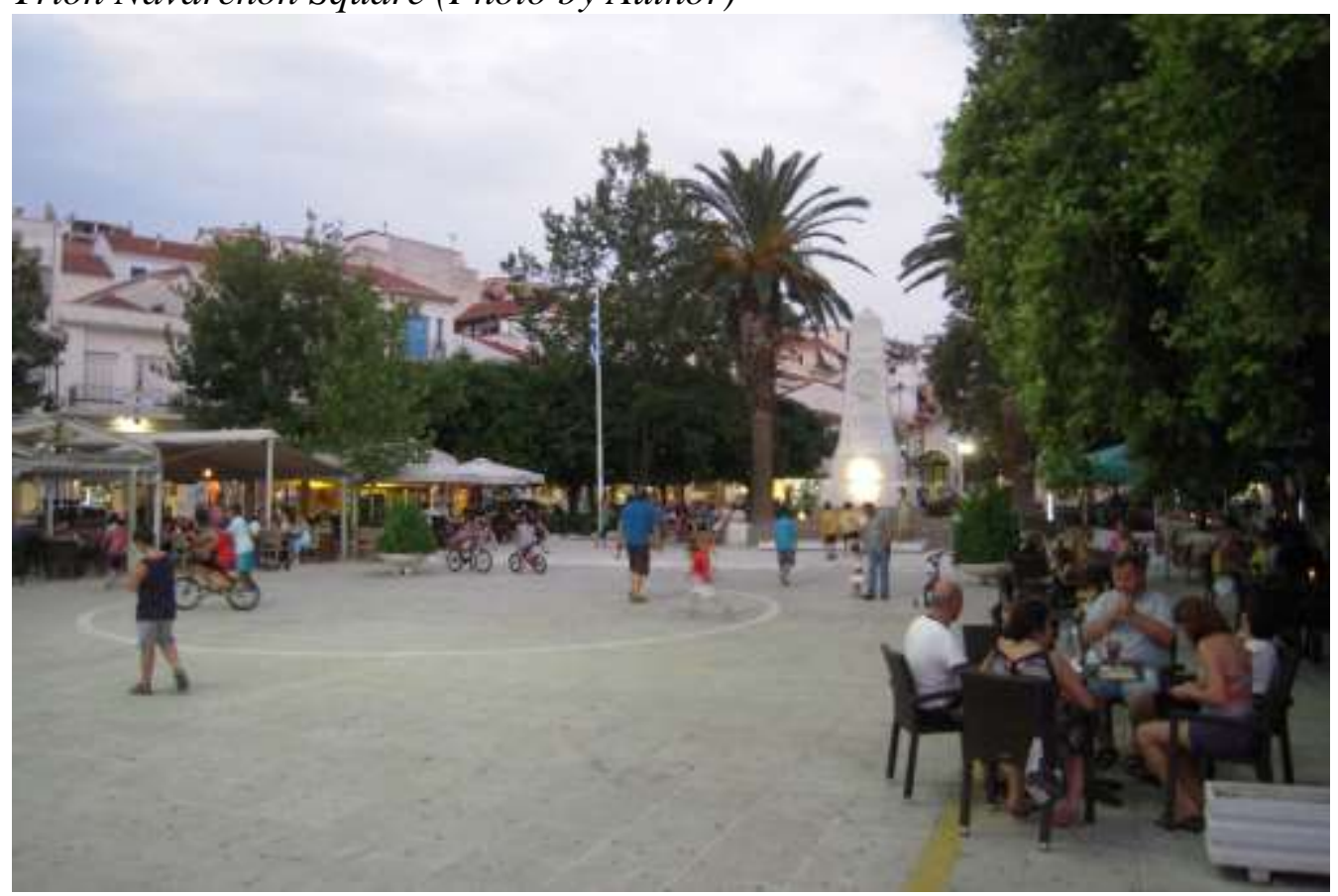

\section{Case Study 2: Ammothines Restaurant, Petrochori}

Ammothines Restaurant opened in 2012, in the village of Petrochori. This beachside restaurant has views of the Ionian Sea and is surrounded with approximately 320 square meters of production garden. The integration of food-systems is a clear concept of the restaurant, which includes production, processing, distribution, retail, and celebration.

\section{Production, Processing \& Distribution}

A variety of crops are grown and processed on-site, contributing to daily specials on the menu. The garden emphasizes the simple concept that the kitchen specializes in fresh, local dishes (figure 5). In terms of food security, 
provided that there are no issues that harm the crops, the restaurant is assured a reliable access to quality food. The garden may not provide for all of the restaurant's food needs, however, there will be less of a demand for food imports. Furthermore, as the costs of energy climb, the costs for food-sourcing will also rise. Therefore, growing food at the restaurant will allow the business to lower the expenses associated with food imports.

Figure 5. The Menu at the Restaurant Changes Daily, based on what is Available in the Garden. Ammothines Restaurant, Petrochori (Photo by Author)

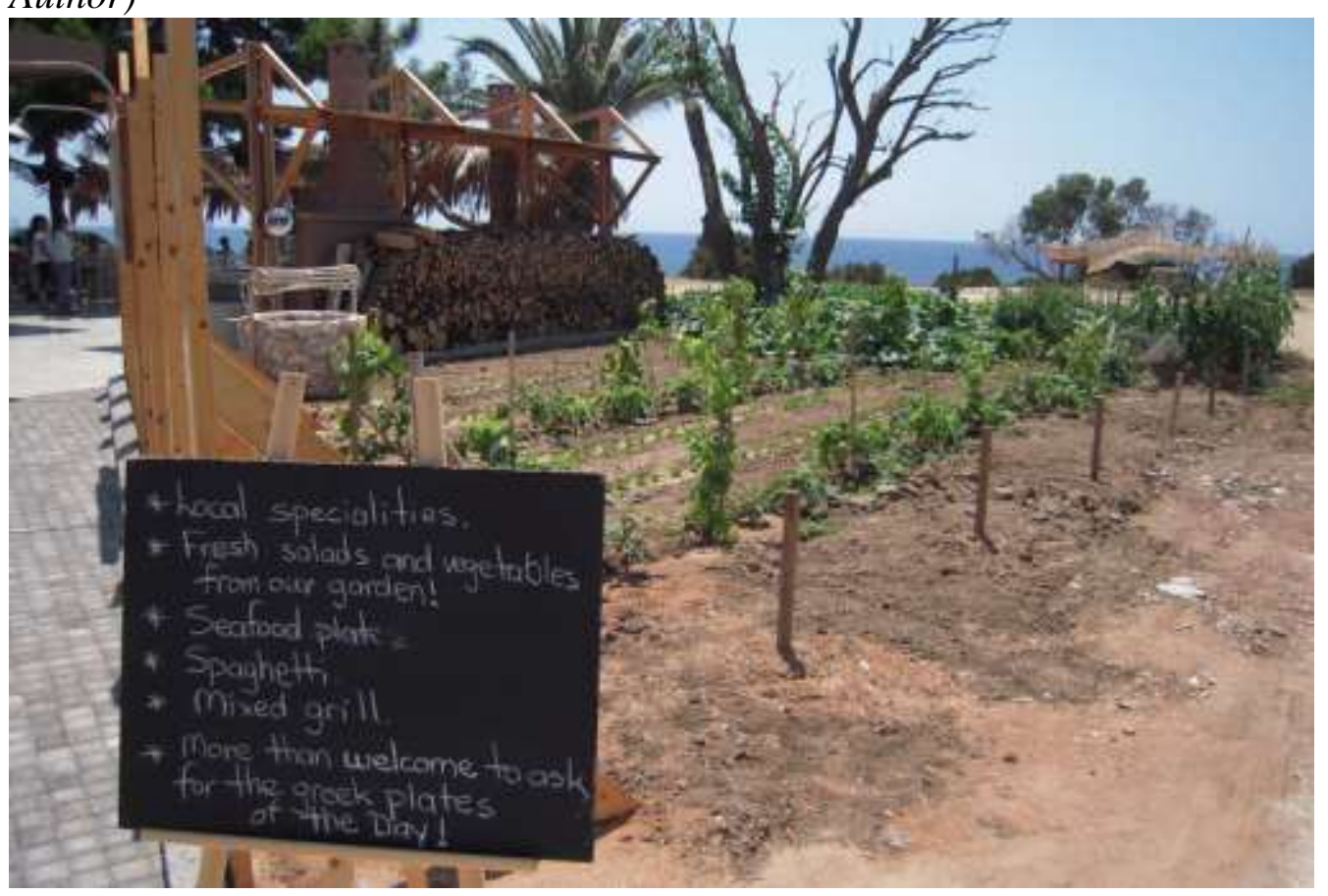

Retail

The food grown on-site is utilized at the restaurant and not packaged and sold for other retail opportunities. However, from a marketing point of view, the effect of sitting beach side, surrounded by a vegetable garden is a positive draw for customers. The act of growing food at the restaurant not only inspires confidence in customers that the food will be good, but also enhances the experience of dining in a positive manner.

\section{Celebration \& Eating}

The garden allows customers the opportunity to see where their food originates. Again, the concept of making food visible emerges. This outdoor dining experience is set on a large patio, defined by the open-concept kitchen building at one end and an outdoor oven and bar at another. The rest of the dining patio is surrounded by the vegetable garden, with thatched umbrellas providing shade (figure 6). 
Figure 6. View of the Shaded Dining Patio Set within the Garden. Ammothines Restaurant, Petrochori (Photo by Author)

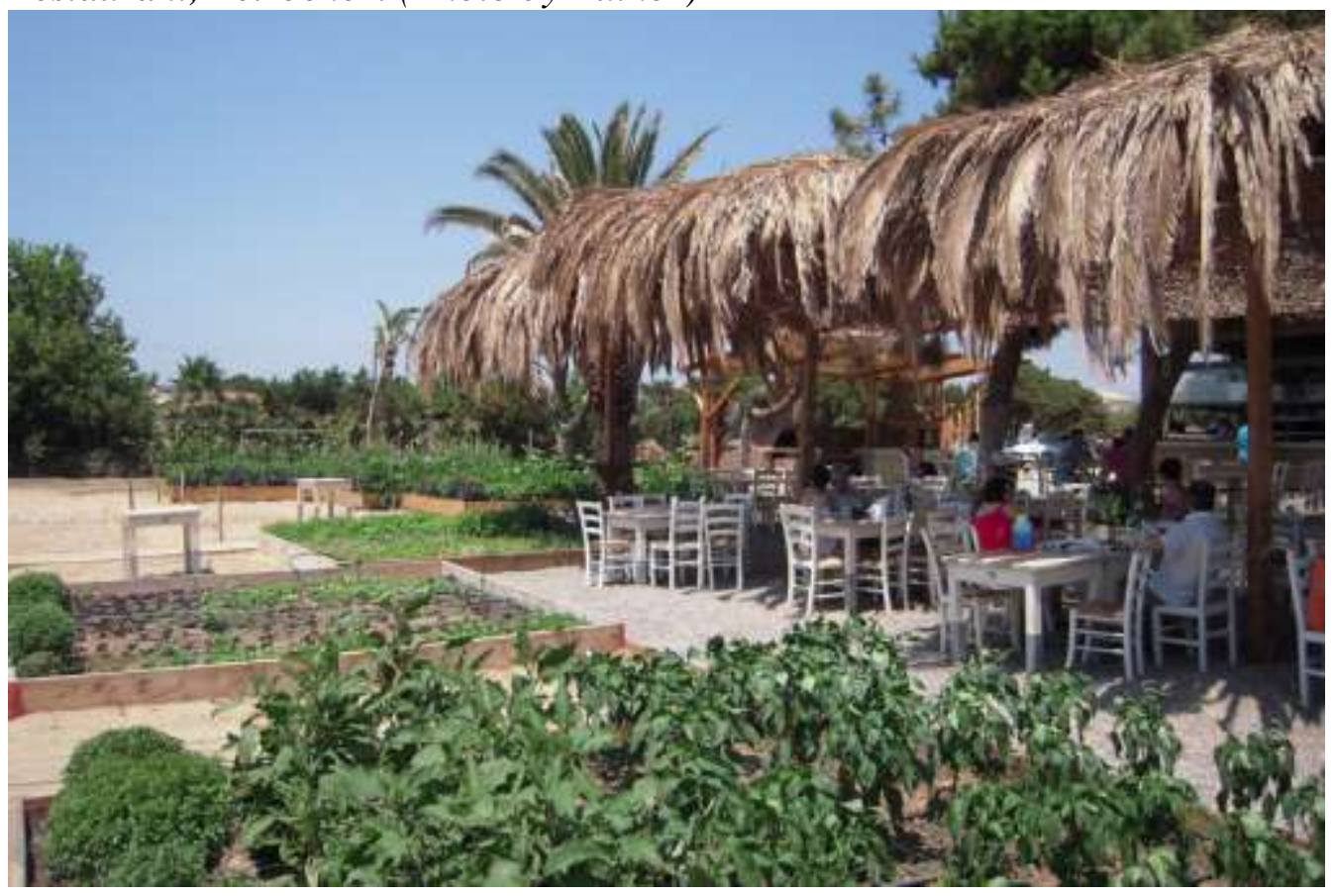

\section{Waste Recovery \& Education}

Observation of the restaurant does not reveal a sustainable system for waste recovery, such as composting organic kitchen waste to build healthy soils in the garden. Aside from waste recovery, there are no formal educational components to the operation. The value of making the kitchen somewhat transparent begins to fulfill educational roles by revealing to diners how their food is prepared. However, there are no formal interpretive elements, such as signs to identify plants or crop in the garden. In the agricultural-based landscape of Messinia, locals may very well know the types of crops growing in the garden, but international visitors may not. The opportunities for sharing local knowledge on food are revealed through the following case study.

\section{Case Study 3: Navarino Dunes Resort, Romanos}

The Navarino Dunes Resort is the first site of the Costa Navarino development, occupying a 130-hectare site along a one-kilometer waterfront length overlooking the Ionian Sea. The 766-room resort opened in 2010 and has two accommodation options that include The Romanos, a Luxury Collection Resort and the Westin Resort. Amenities include two signature championship golf courses, a spa, conference facilities, shops, restaurants, bars, and cafes. The design integrates the concept of a traditional village with the natural landscape (figure 7).

The cultural landscape of Messinia has been reflected in both the architecture and landscape of the resort. Traditional local architectural 
proportions have been used in the design of the doors and windows throughout the resort, as well as customary materials, such as stone, wood, plaster, and marble. In the landscape, the icon of the olive tree, which is linked with Greek mythology and tradition, has been utilized in the planting scheme of the resort. Approximately 6,500 olive trees have been transplanted from the construction site of the resort with a 99\% success rate (Kallos 2011). The trees are part of a program started in 2004 to transplant olive trees. Once the program has been completed, it is expected that 16,000 trees will have been replanted in all areas that will be developed in Costa Navarino.

Figure 7. Traditional and Modern Architecture are Interwoven with the Natural and Cultural Landscapes of Messinia. Navarino Dunes Resort, Romanos (Photo by Author)

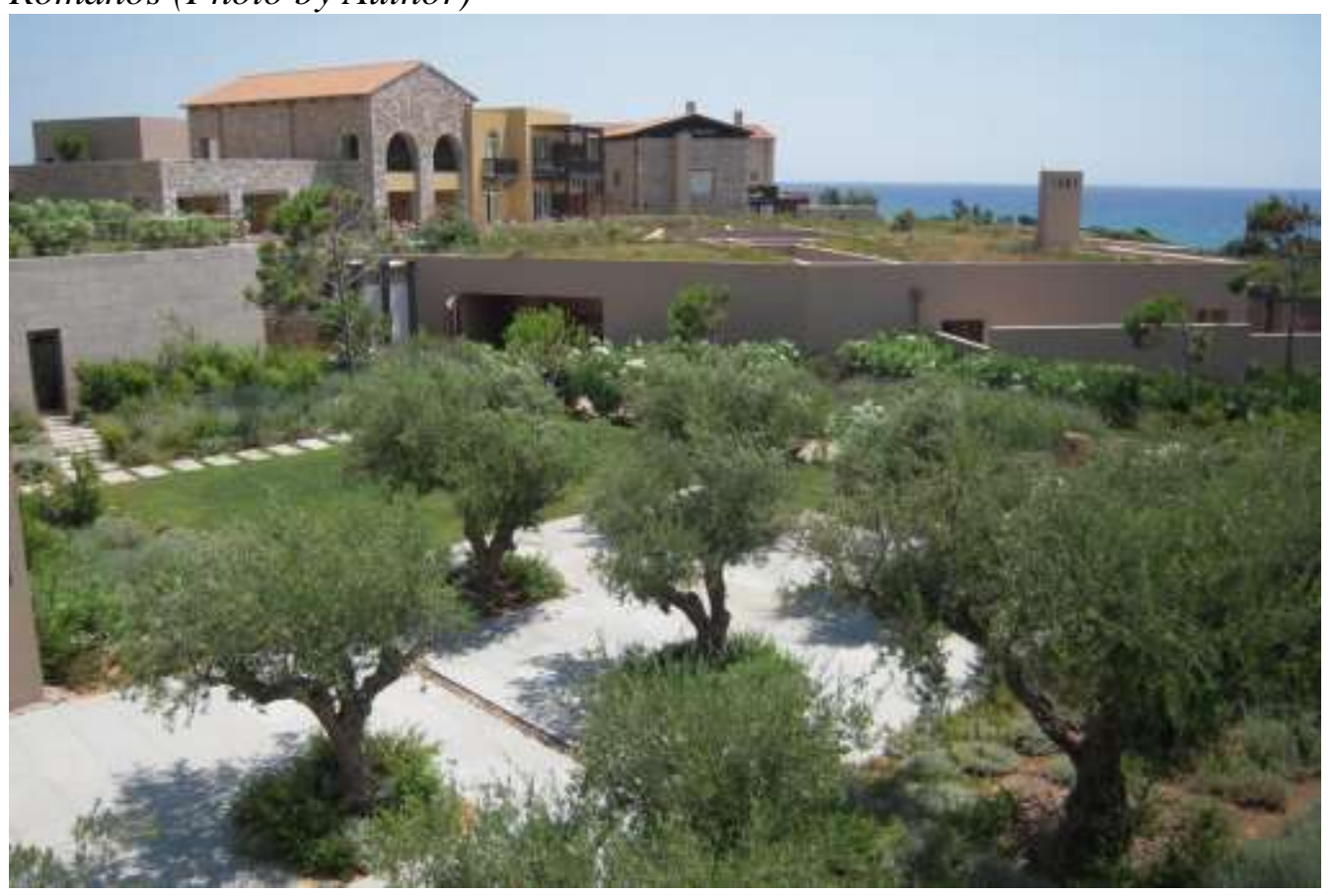

\section{Production, Processing \& Distribution}

In terms of production, the resort has on-site herb and vegetable gardens where several ingredients for the restaurants are grown (figure 8). These gardens were not part of the original design for the resort, but were added. Typical crops include celery, dill, spinach, leeks, lettuce, tomatoes, peppers, zucchini, carrots, beets, cucumbers and eggplant. Additional foods for the restaurants are mostly sourced within 150 kilometers of the resort. In addition to having an herb and vegetable garden for fresh, daily ingredients, olive oil is manufactured from the resort's olive trees. The oil is pressed from olives picked the same day, ensuring its high quality, and is used by the chefs at the resort's restaurants. Furthermore, the benefits of processing olive tree products at the resort go beyond restaurant use, and are also used at the resort's spa. 
Figure 8. View of the Production Garden at the Resort. Navarino Dunes Resort, Romanos (Photo by Author)

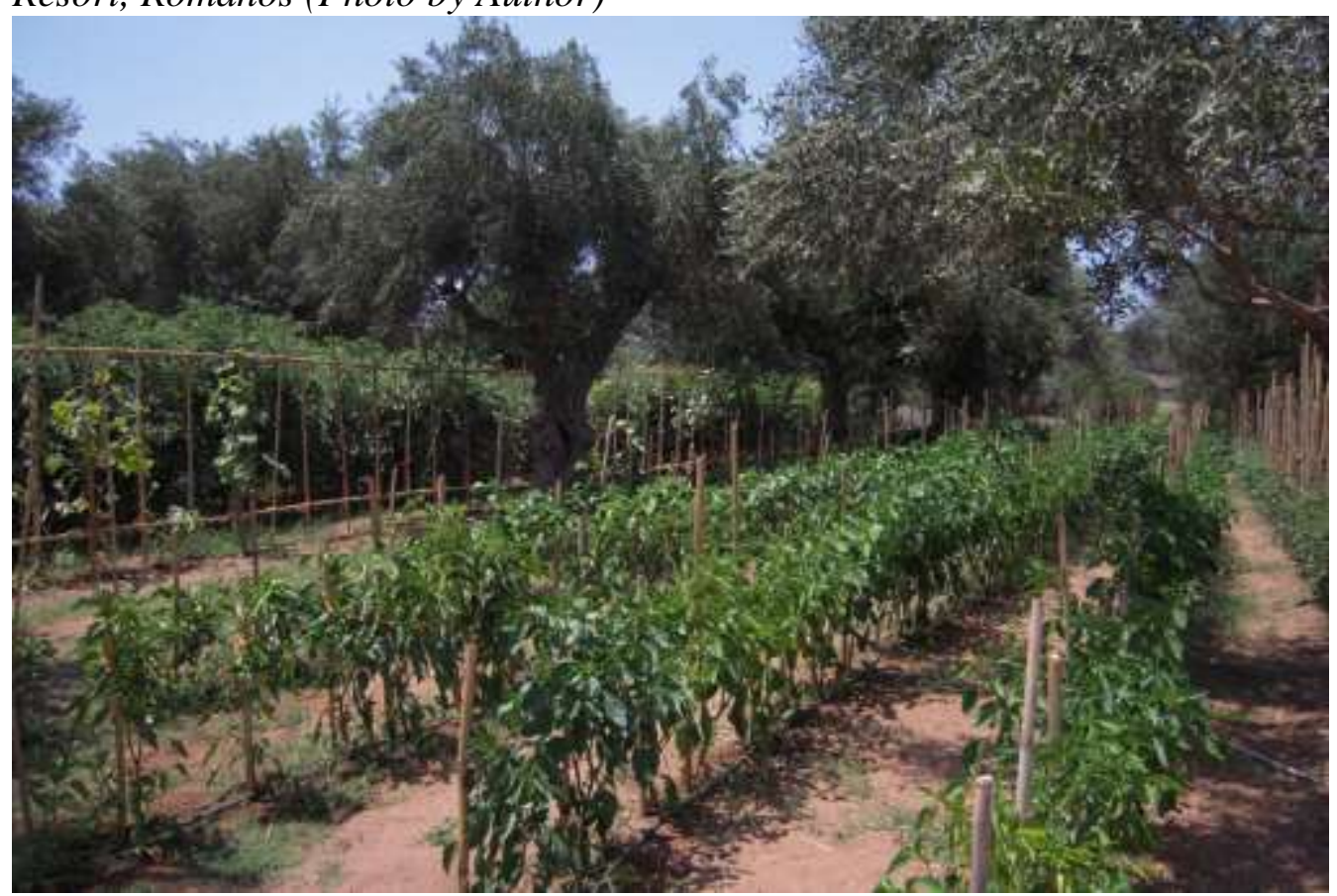

\section{Retail}

Costa Navarino markets and sells its own line of culinary products, based on traditional, local recipes. Examples include honey, olive oil, and lemon marmalade, to name a few. The ingredients are grown and processed using small-scale local producers and from its own estates. The inclusion of food products for retail from these producers supports a local food movement and contributes to the local economy. Establishing a network of farms allows Costa Navarino to be an aggregator of local food, working together with the producers to create the products and selling to consumers.

\section{Celebration \& Eating}

The local food movement is further emphasized in the celebration of food at the resort. Food is sourced for the restaurants through local organic and heirloom producers. A number of the resort's restaurants are focused on traditional cuisine based on local ingredients and dishes based on the Omega Diet are a prominent theme. Flame, uses only local produce, including fresh produce from the resort's own gardens. Other restaurants emphasizing local ingredients and recipes are Eleon, specializing in fresh fish and seafood, as well as Taverna, that revives favorite Greek and local recipes. In addition to a focus on local food, other restaurants include of mix of Greek, ethnic and international cuisine that includes a 1960s inspired diner that features American cuisine.

The restaurants have been strategically located throughout various locations at the resort — poolside, overlooking a golf course, or the seaside. Like the main square in Pylos and other settlements in Messinia, the resort has 
a central platia that is flanked by restaurants, as well as shops and other amenities such as an open-air movie theater. The outdoor patios of the restaurants contribute to the positive animation of the resort as people to gather to eat and drink.

\section{Waste Recovery}

In terms of a sustainable systems approach to waste recovery, the resort has been designed using best management practices (BMPs) for storm and surface water management. BMPs are the primary method to control storm and surface water discharges. To illustrate, the resort makes use of two constructed reservoirs with a total capacity of 700,000 cubic meters, to collect and store approximately $2 \%$ of excess runoff from the Sellas, Xerias and Yanouzagas Rivers (TEMES 2014, 14-5). The harvested water, in combination with treated wastewater from the resort's treatment plant, is enough to support the irrigation needs of the golf courses and landscape and prevent drawing from the potable water source of the area. As a result, this practice contributes to a sustainable agricultural practice related to irrigation and growing food.

Figure 9. The Learning Kitchen at Taverna. Navarino Dunes Resort, Romanos (Photo by Author)

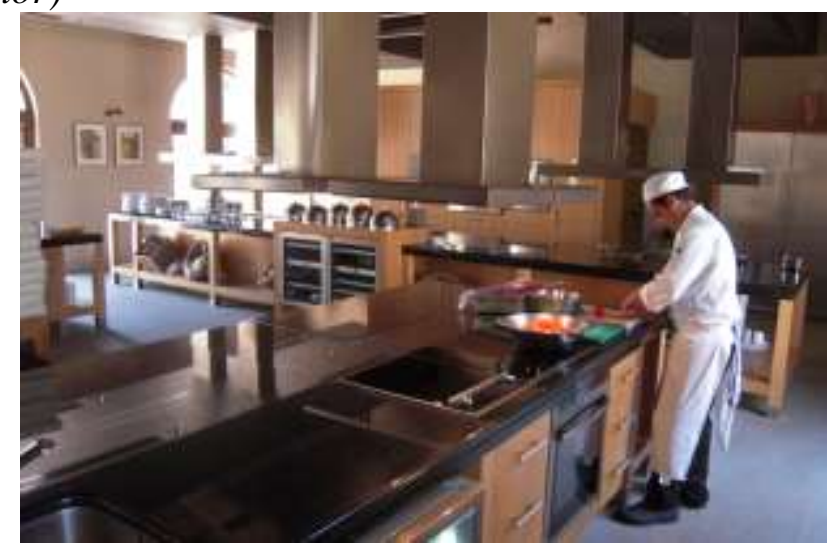

\section{Education}

The resort presents many unique experiences and workshops for guests connected to the cultural landscape, including food related topics, such as cooking classes with local women, teaching traditional techniques and local recipes. The previously mentioned restaurant, Taverna is equipped with a learning kitchen, where cooking classes from the resort's chefs can take place (figure 9). The resort is in the process of developing cooking classes for children, with the goal to raise awareness on healthy eating. Other programs include participating in the harvesting of grapes for the production of wine that takes place August and early September, and wine tastings and seminars scheduled with renowned sommeliers and wine specialists. More physical activities for guests include learning about the process and production of olive oil by participating in the traditional olive harvest from September to December, while also joining olive-oil tasting sessions. 


\section{Proposed Greenpoint Food District, Brooklyn, USA}

A collaborative design team from Las Vegas, Nevada, developed the concept of the Greenpoint Food District (figure 10) as part of the Living Cities: Residential Towers for the $21^{\text {st }}$ Century Design Competition. Greenpoint is the northern most neighborhood of Brooklyn. The area was farmland from the 17th through to the early 19th centuries (Burden 2005, 7-4). Today Brooklyn is an urban landscape with its population rediscovering its agricultural roots with a variety of organic food companies operating production facilities. Some examples include McClure's Pickles, a manufacturer of pickles and other products such as relish and potato chips (McClure's Pickles 2014), and the Eagle Street Rooftop Farm (560 square meters) and Brooklyn Grange (3,700 square meters), rooftop farms growing vegetables and herbs, as well as producing eggs and honey (Gorgolewski 2011, 158-63). This cultural rediscovery served as the inspiration for the project concept - to develop a pedestrian oriented, compact, regenerative community that has a clear identity with food cultivation.

Figure 10. Concept Plan of the Proposed Greenpoint Food District. (Drawing by Author)

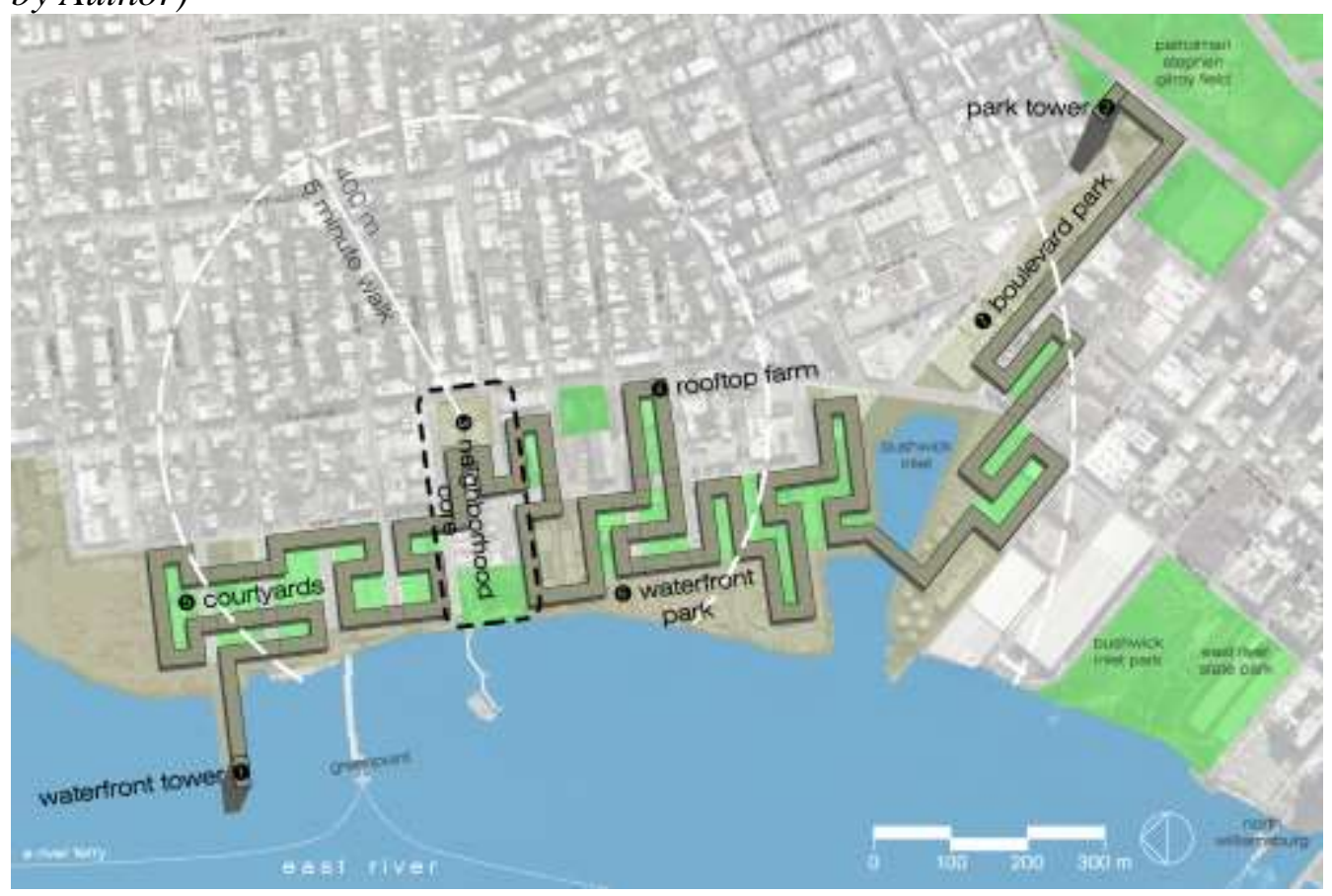

The proposed site selected by the design team for the project is the industrial land that is part of the almost 200 block rezoning effort in the Greenpoint and Williamsburg neighborhoods, passed by the New York City's Department of City Planning in 2005 (NYC Planning 2005). The rezoning is designed to bring over 16,000 new residents to the area with supporting commercial and civic amenities (Burden 2005, 1-32). Included in the new 
zoning is a public park along the East River that is to extend to Newtown Creek.

To respond to the zoning, the team developed a single, four-story, building typology designed around the concept of integrated food-systems with education. The proposed building will include a mix of civic, retail, office, and residential uses. Figure 11 illustrates how these systems have been integrated to create the concept for the proposed Greenpoint Food District.

Building form and landscapes are carefully interwoven to create the District. A compact neighborhood core will serve as the primary focus for work, culture and entertainment for the District's residents and visitors. The study of the cultural landscape of Messinia provided the precedent for the successful integration of food-systems with the built environment.

Figure 11. The Integration of Sustainable Food-Systems within the Greenpoint Food District (Illustration by Torrey Tracy, 2013)

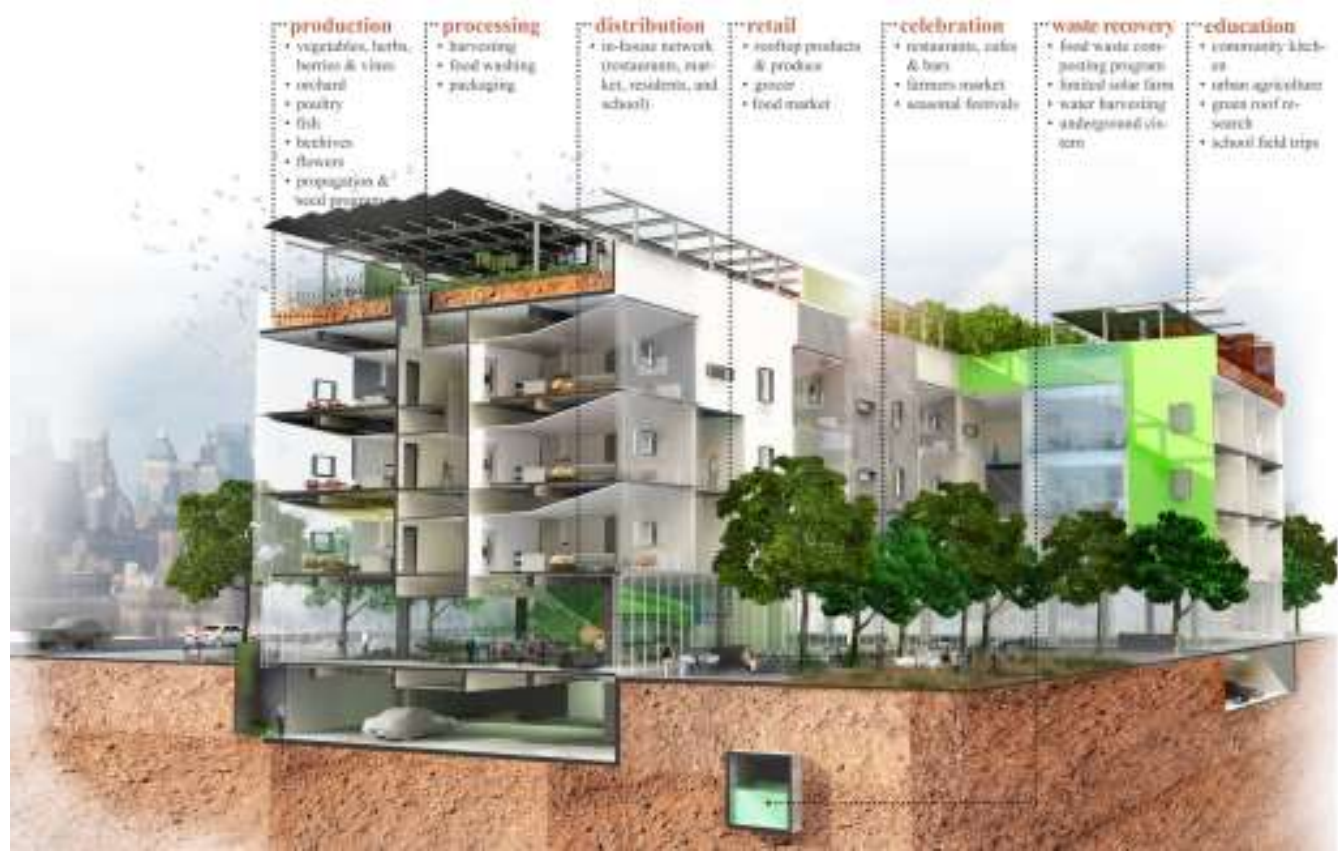

Production, Processing \& Distribution

As demonstrated by Ammothines Restaurant and the Costa Navarino Resort, the value of production, processing and distribution of food within the District are integrated through the proposed design. Half of the 110,000 square meter rooftop will be dedicated to food production, while the remaining $30 \%$ will be required for mechanical systems and maintenance circulation, and $20 \%$ set aside for residential amenities including outdoor kitchens, patios and gardens (figure 12). Proposed production will include a mix of soil-based growing and aquaponics, and will include a variety of crops.

Aside from production, the processing of food at the District will involve harvesting, food washing, and packaging. Once processed, food will be distributed within an in-house network that will include a market, school lunch program, restaurants, and a residential Community Supported Agriculture 
(CSA) program. As food in the district will be grown where it will be sold, the unique opportunity will be to grow produce based on its flavor and nutritional content, rather than the attributes desirable for traveling long distances - the typical meal in the United States travels approximately 2,400 kilometers from farm to plate (Suzuki: 2008, 54).

Figure 12. 50\% of the Rooftop will be Dedicated to Food Production, while the Remaining Deck will be Utilized for Mechanical Systems, and Residential Amenities. Greenpoint Food District (Illustration by Torrey Tracy, 2013)

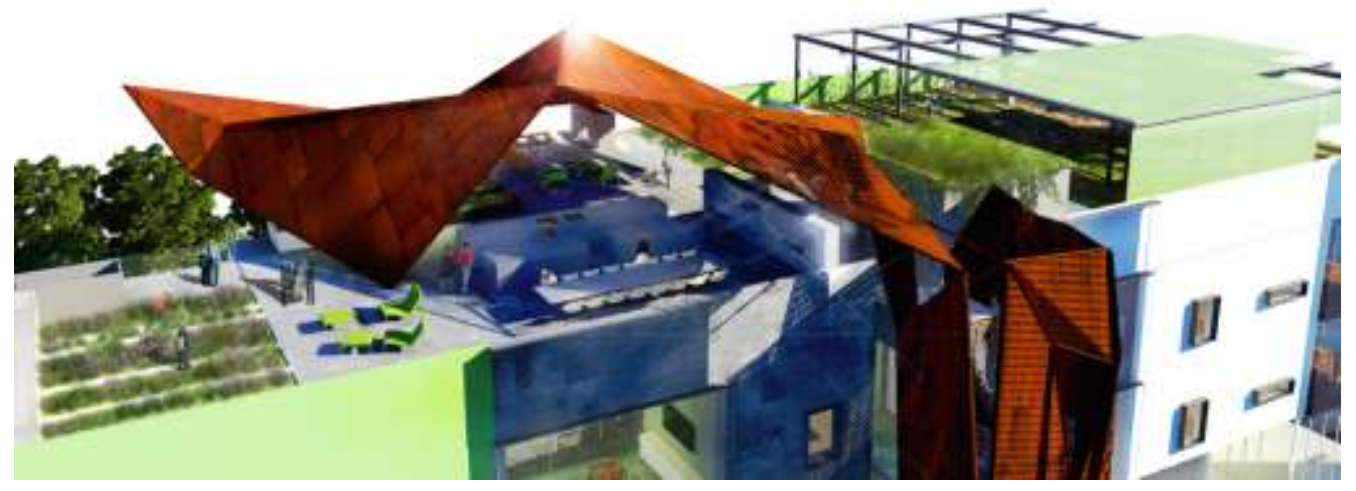

Retail

A number of lessons learned from the cultural landscape of Messinia inform the retail and marketing opportunities for food in the Greenpoint Food District. As the Costa Navarino Resort markets and sells its own line of culinary products, so will the District. Examples of products produced from the rooftop farm will include heirloom vegetables, honey, and fish from the aquaponics operation. Partnerships with small-scale local producers will also be established to offer a wider range of foods. The local economy of the District will be fostered through the sale of the products at the weekly farmers market, grocery, and corner stores. To illustrate, an estimate of 7,000 to 9,000 kilograms of food will be produced daily from the rooftop. This could translate to approximately 50,000 food baskets per week for a CSA program. If baskets start at $\$ 35$, then revenue is expected to be $\$ 1.75$ million per week. Money spent on the production, processing, and consumption of the food from the farm will stay in the community. Finally, the organization of the District places commercial activity in a location that will provide residents with most of their daily shopping needs within an eight to ten minute walking distance. As shown by Trion Navarchon Square, the compact, pedestrian oriented scale, will offer its future residents access to amenities essential for daily life.

\section{Celebration \& Eating}

The concentration of restaurants and cafes along the District's main plazas and streets, will contribute to neighborhood vibrancy (figure 13). As illustrated with Trion Navarchon Square and the Costa Navarino Resort, the District's plazas will be lined with outdoor patios where restaurants will extend out onto the edge of the sidewalk, providing places to eat and celebrate. Restaurants will 
have the opportunity to feature food from the rooftop farm as well as other local suppliers, contributing to seasonal menus. Outdoor venues for dining patios will include sidewalks, plaza and the District's rooftop. Aside from the integration of restaurants and cafes, seasonal celebrations around food are proposed for the District. Inspired by the programs that celebrate cultural traditions at the Costa Navarino Resort, such as the olive harvest, a rooftop celebration at the farm during picking season will contribute new meaning to the annual Fall Harvest Festival in Brooklyn.

Figure 13. A Vibrant Plaza Contributes to the Visibility of Food. Greenpoint Food District (Illustration by Torrey Tracy, 2013)

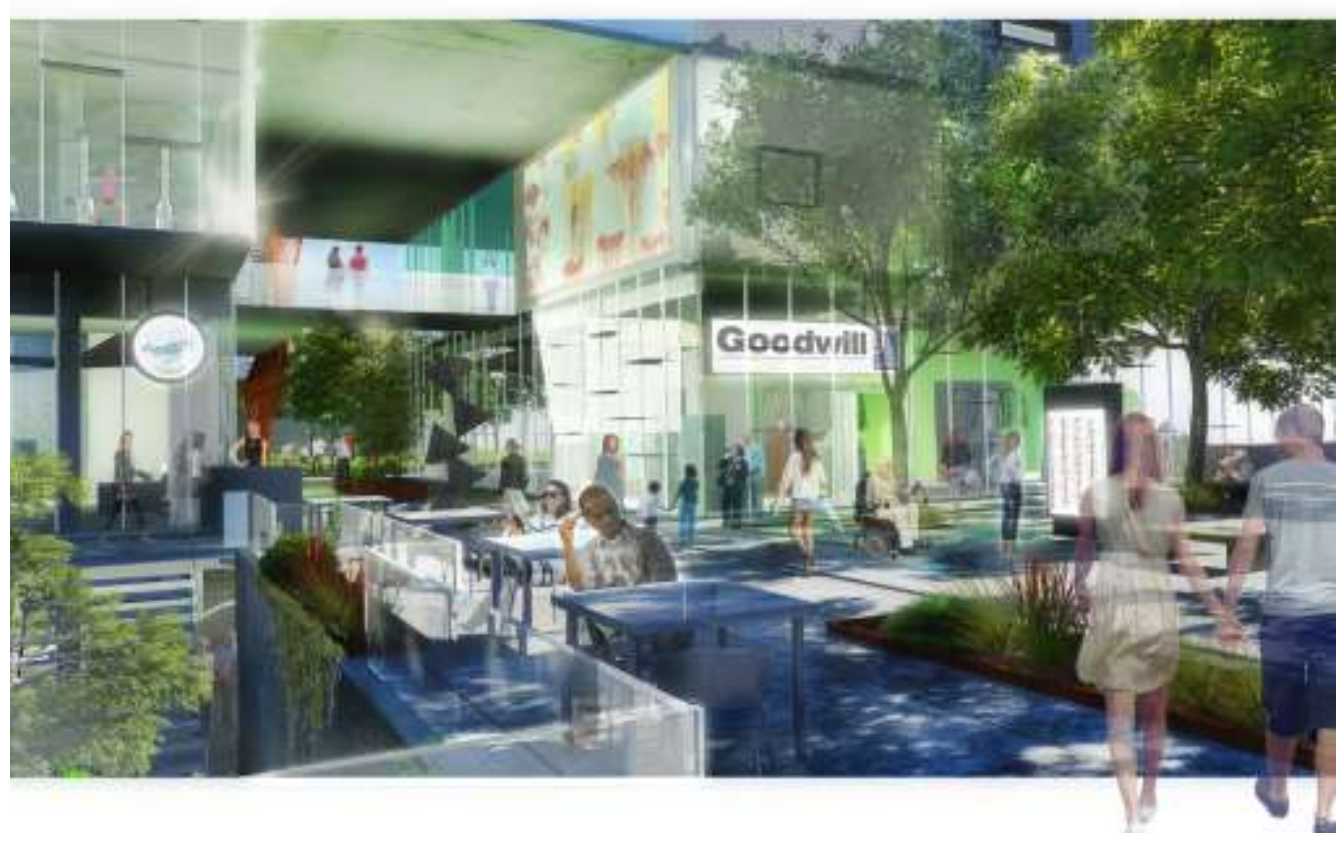

Waste Recovery

As shown by the use of BMPs for storm and surface water at the Costa Navarino Resort, a number of waste recovery systems have been proposed for growing food in the District. A food waste composting program for both residential and commercial tenants provides the opportunity for organic food wastes, landscape, and agricultural wastes be collected for composting and used as a mulch and soil amendment at the farm. Aside from the waste recovery of organic wastes, opportunities for solar energy capture will be integrated with solar cells positioned strategically on the roof, not to interfere with food production. The cells will power the pumps and heaters required for the aquaponics system, and will reduce the overall energy consumption required by the farm.

Finally, the water needs for the landscape of the District will be addressed through regenerative design. Regenerative describes a design approach where natural processes, minimal use of nonrenewable resources, and the use of renewable resources are considered (Lyle 1994, 10-11). In terms of water 
management, this means efficiently using and harvesting water. As a result, a drip irrigation system will make use of on-site harvested water from three sources: rainwater, HVAC condensate, and graywater. Blackwater, the wastewater from toilets, dishwaters, and kitchen sinks will not be collected due to issues of scale for treatment and storage. Harvested water will be treated and stored in an underground cistern on-site. The water will then be used for irrigating the rooftop farm. Excess water will be directed to an on-site wetland.

Figure 14. A Variety of Educational Programs will be offered at the District, such as Tours of the Rooftop Farm to Educate Participants about Food. Greenpoint Food District (Illustration by Torrey Tracy, 2013)

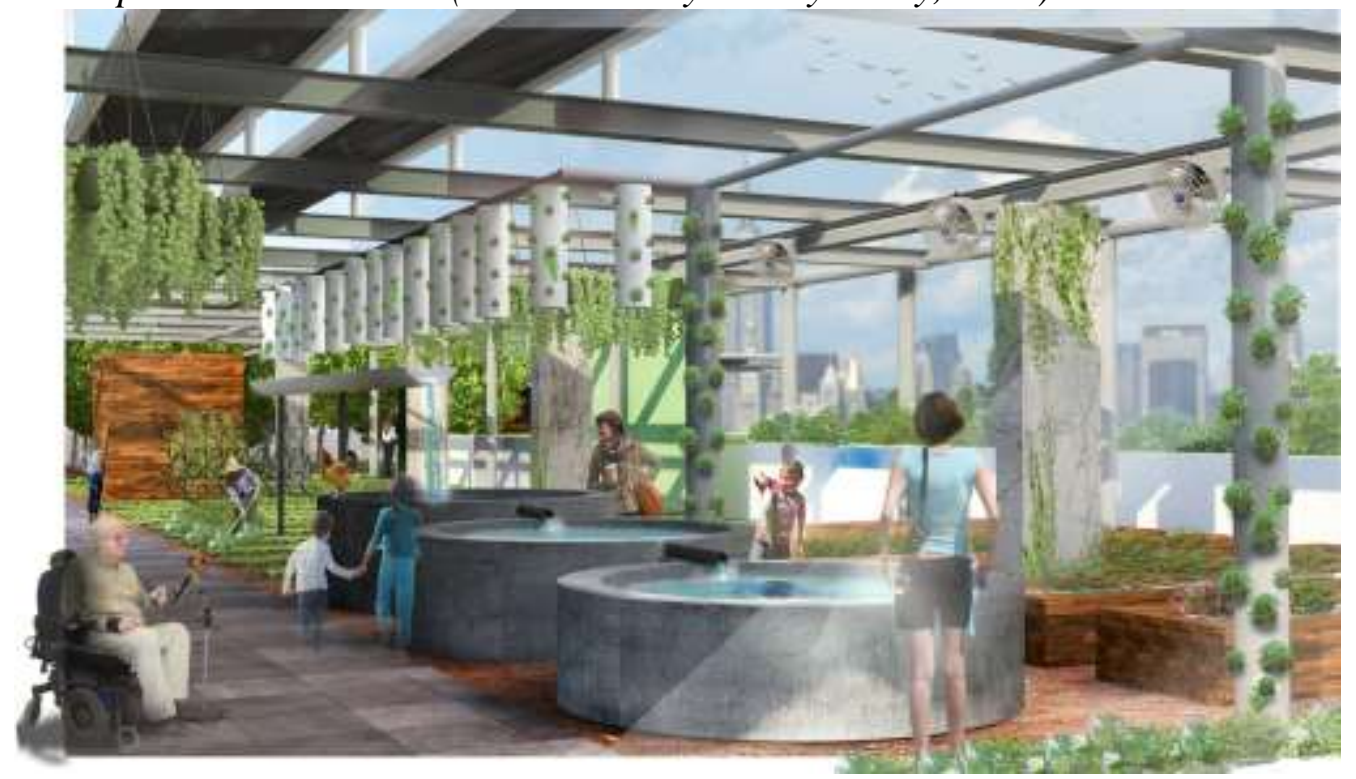

\section{Education}

As demonstrated by the variety of guest activities related to food at the Costa Navarino Resort, a series of educational programs for residents and visitors are proposed for the Greenpoint Food District. The rooftop farm will provide the opportunity to host food related activities and training courses that will encourage social participation. For example, programs will include a community kitchen that will unite participants learning to cook, share recipes, and most importantly, provide them with healthy food advice and meal planning options. Program participation will help people learn new skills, gain self-confidence, and contribute to their personal health by giving them the tools to make healthy choices (Iles 2005). Other potential programs include integrating the farm with preschool activities, afterschool programs, school visits, work-placement programs, and other community programs and enterprise that will further strengthen the neighborhood (figure 14). 


\section{Conclusions}

In a place where agriculture is a way of life, such as Messinia, the inherent lessons of food may appear obvious (figure 15). However, in the urban environment of our cities, food-systems are often hidden from view or absent. As shown by the design of the Greenpoint Food District, a study of the cultural landscape of Messinia, Greece, provides lessons for the agricultural urbanism movement on how food-systems can be successfully utilized in the shaping and making of places.

Figure 15. The Olive Tree is Part of the Cultural Landscape of Messinia. Navarino Dunes Resort, Romanos (Photo by Author)

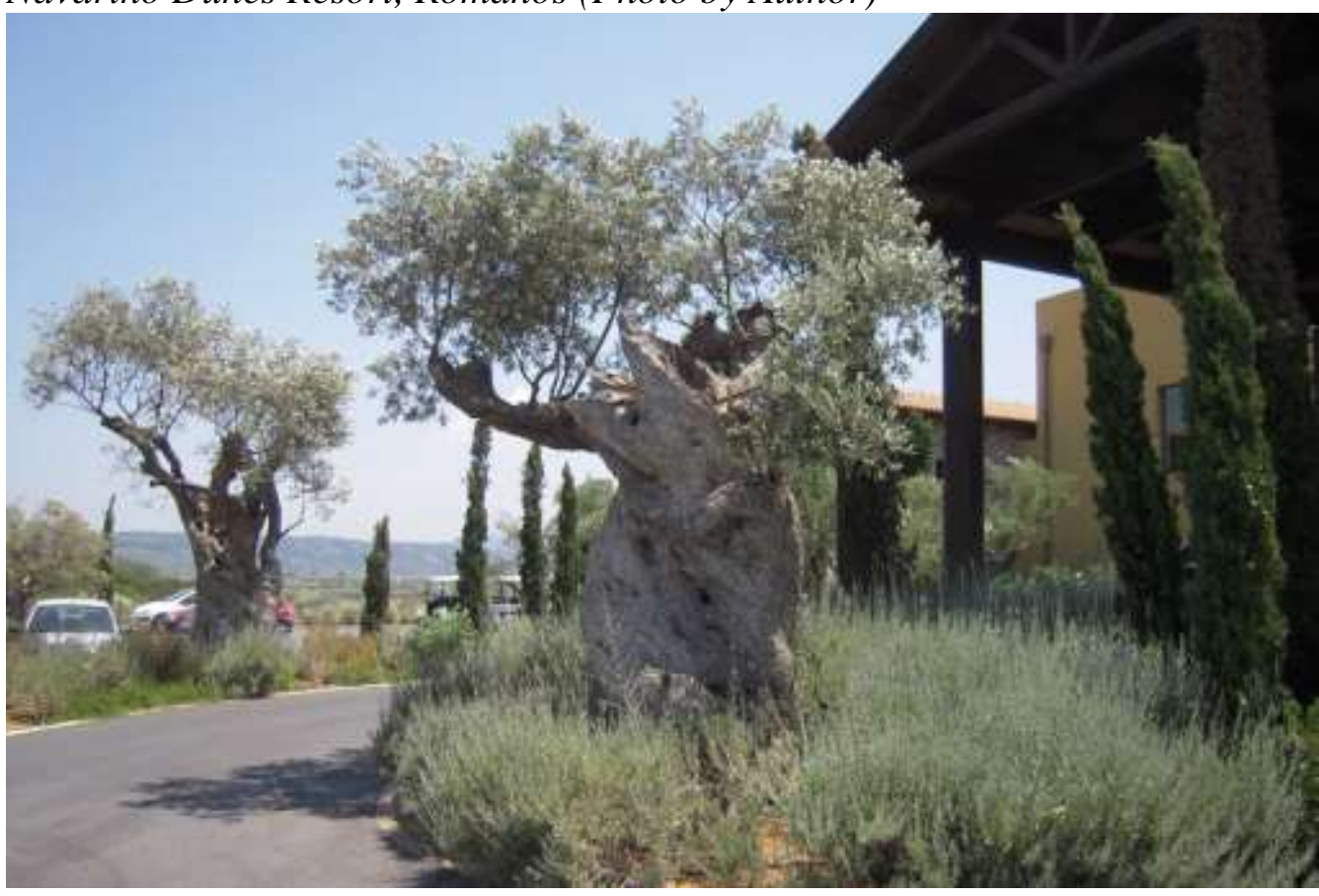

Key lessons on how food can be integrated with the urban environment from Trion Navarchon Square, include designing the pedestrian realm for human comfort and scale that contributes to positive experiences for food related retail and celebration; pattern town streets and plazas to support a compact neighborhood with a variety of food sources within a ten-minute walk; and integrate food with the everyday life of the urban environment in a meaningful manner. Designing for active dining patios and including space for street vendors are examples of making food visible. Including spaces for celebration such as food festivals and other cultural events are examples of making food meaningful in city life.

The lessons that emerge from Ammothines Restaurant, include growing and selling local food at an eatery will contribute to the eat local movement; production will drive the daily menu based on what is in season and ready to harvest; and the value of making food visible in the built environment has the 
potential to fulfill educational roles, as well as adding delight to the experience of dining.

A case study of the Costa Navarino Resort, teaches many lessons, including, cultivation can serve to inspire those that process and prepare food, such as the chefs of the resort; the processing and distribution of food on-site allows for not only a fresh source of food in the restaurants, but for other retail and marketing opportunities; networking with small-scale local producers provides the opportunity for the resort to act as an aggregator of local food; restaurants focused on traditional cuisine based on local ingredient support the local food movement; locate restaurants strategically to take advantage of the relationships in the landscape, such as outstanding views or adjacencies; utilize BMPs for the sustainable recovery and use of waste materials; and develop and implement a variety of educational programs related to food in order to meet the diverse tastes of people.

As the world's population increases and the amount of farmland shrinks, there must be a shift in how we shape our urban environments. The lessons learned from the cultural landscape of Messina, provide an opportunity to better understand how to successfully integrate food with our urban environments. Food provides the opportunity to restore, invigorate, and transform how we make our communities and cities better places to live, learn, work and play. Addressing these challenges through agricultural urbanism provides the mechanisms required to shape the city into a distinct place dedicated to food.

\section{Acknowledgments}

I wish to thank the following people for enabling me to visit their offices and Navarino Dunes Resort: Mr. George Hadjiosif, Chief Destination Officer, TEMES S.A.; Mr. Fotis Stavrianopoulos, Operations Associate, TEMES S.A.; Ms. Natasa Glaraki, Assistant to the Chief Destination Officer, TEMES S.A.; Mrs. Valia Vanezi, Senior PR \& Media Relations Manager, TEMES S.A.; Ms. Maria Linardopoulou, Architect, TEMES S.A.; Ms. Pagona Eleni, Architect, TEMES S.A.; Mr. Harry Bougadellis, Architect, LEEAD; Mr. Richard Sather, Architect, LEEAD; Mr. Christos Choudeloudis, Architect, AETER; and Ms. Lambrini Litsa, Customer Services Manager, Navarino Dunes Resort. I would also like to recognize my collaborators on the Greenpoint Food District: Mr. David Baird, AIA, and Mr. Torrey Tracy, M.Arch.

\section{References}

Burden, Amanda M., chair. 2005. Greenpoint-Williamsburg Rezoning: Final Environmental Impact Statement. City Planning Commission, City of New York. de la Salle, Janine \& Holland, Mark, editors. 2010. Agricultural Urbanism: Handbook for Building Sustainable Food Systems in $21^{\text {st }}$ Century Cities. Winnipeg: Green Frigate Books. 
Gorgolewski, Mark, Komisar, June \& Nasr, Joe. 2011. Carrot City: Creating Places for Urban Agriculture. Singapore: Random House.

Iles, Jeremy. 2005. The Social Role of Community Farms and Gardens in the City, in CPULs: Designing Urban Agriculture for Sustainable Cities, edited by Viljoen, Andre. Oxford: Architectural Press.

Kallos, Marios, "Olive Culture," Costa Navarino Stories: The Costa Navarino Magazine (No.1), 2011, 54-8.

Kouvelakis, P. 2006. Greece: Peloponnese. Greek National Tourism Organization, Publications and Audiovisual Means Department. Athens: Archaeological Receipts Fund.

Lyle, John Tillman. 1994. Regenerative Design for Sustainable Development. New York: John Wiley \& Sons.

McClure's Pickles, "Our Story," accessed November 14, 2014. http://www.mcclures pickles.com

NYC Planning. "Greenpoint-Williamsburg." published on the web May 11, 2005, http://www.nyc.gov/html/dcp/html/greenpointwill/greenoverview.shtml

Papathanassopoulos, George \& Papathanassopoulos, Thanos, 2000. Pylos - Pylia: A Journey Through Time and Space. Athens: Archaeological Receipts Fund.

Suzuki, David \& Boyd, David R., 2008. David Suzuki's Green Guide. Vancouver: Greystone Books.

TEMES S.A., Costa Navarino: Environmental Best Practices, accessed June 4, 2014. http://www.costanavarino.com/\#/downloads/brochures

The Cultural Landscape Foundation, "What are Cultural Landscapes," accessed June 4, 2014. http://tclf.org/landscapes/what-are-cultural-landscapes 